\title{
SPATIAL VARIABILITY IN BEACH MORPHOLOGY WITH RESPECT TO WAVE EXPOSURE ALONG A ZETA-SHAPED COASTLINE
}

\author{
THOMAS MURRAY ${ }^{1}$, DARRELL STRAUSS ${ }^{1}$, GUILHERME VIEIRA DA SILVA ${ }^{1}$, \\ COURTNEY WHARTON ${ }^{2}$
}

1. Griffith Centre for Coastal Management, Griffith University, G512.07 Gold Coast Campus, QLD 4216,Australia.t.murray@griffith.edu.aul d.strauss@griffith.edu.aul g.vieiradasilva@griffith.edu.au ${ }^{l}$

2. City of Gold Coast, PO Box 5042 Gold Coast Mail Centre QLD, 9729, Australia. cwharton@goldcoast.qld.gov.au ${ }^{2}$

\begin{abstract}
Regular, high spatial resolution survey datasets from dune to depth of closure are rare in the literature. These type of datasets have the ability to provide critical information about changing beach morphodynamics in both the two and three-dimensional space. A regional experiment was established for the open ocean beaches of the Gold Coast, Australia. Two years of high spatial frequency survey at five sites within the Gold Coast embayment are presented here. This paper details the usefulness of the unique dataset and its ability to further inform previously poorly understood coastal morphodynamic questions, such as bar migration and spatial variability in beach state energy with respect to wave direction. By comparing the spatial variability in beach morphology between the survey sites, under two different wave directions, it is shown that the wave direction and attenuation play an important a role in shaping bar morphology along the coast. The insights gained from this expanding dataset will aid in the planning and management of zeta-shaped coastlines at both local and regional scales. Specific areas of the coast may be targeted for different management and hazard mitigation strategies under different wave directions, storm events and/or accretionary periods as sections of the coast will respond differently to the incoming wave energy.
\end{abstract}

\section{Introduction}

Under processes typical of open ocean coastal systems, beaches naturally cycle through periods of accretion (under lowered wave energy) and erosion (during increased wave activity, high water levels and storm events). It is generally accepted that sediment is eroded from the beach and deposited in offshore bars during increased wave energy events (i.e. storm events) through the mechanisms of undertow and rip currents. Whilst it is understood that during low wave energy (i.e. accretionary periods) sediment will slowly migrate onshore, the mechanisms for onshore sediment transport are still poorly understood. Onshore bar migration during relatively low wave energy periods is hypothesised to result from the slightly onshore skewed orbital velocities of nonlinear shallow water waves (Elgar et al., 2001, Hoefel and Elgar, 2003). However this hypothesis has been shown to not accurately predict onshore bar migration near the shoreline and in 
the surf zone (Roelvink and Stive, 1989, Gallagher et al., 1998, Elgar et al., 2001, Hoefel and Elgar, 2003). To date most studies on cross-shore transport rates have focused upon offshore transport (erosion). Onshore transport and bar migration studies are scarce, particularly based on field measurements.

Recently the importance of wave direction on variability in coastal morphodynamics has increased its prevalence in the literature, particularly in terms of coastal erosion (Mortlock et al., 2017, Harley et al., 2017), beach rotation (Short et al., 2001, Klein et al., 2002, Short and Trembanis, 2004, Bryan et al., 2013, Harley et al., 2015), sediment transport (Adams et al., 2011, Bonetti et al., 2012, Vieira da Silva et al., 2017), and beach morphology (Browne et al., 2006, Strauss et al., 2006, Price and Ruessink, 2011, Gallop et al., 2017). It has been shown that over regional scales (e.g. 10's to 100's of km) the effects of exposure of the coastline to the incoming wave energy will vary spatially during storm events (Mortlock and Goodwin, 2015, Mortlock et al., 2017, Harley et al., 2017). This has important implications for beach erosion and in turn mitigation of hazards and management of coastal assets. Alternatively there may be increased rates of accretion along certain sections of coastline. At a more local scale it has been shown through the use of coastal imaging techniques, that variability in local beach morphology on open coast, non-embayed beaches is primarily controlled by wave direction as well as wave energy (Strauss et al., 2006, Price and Ruessink, 2011). Vieira da Silva et al. (2018) analysed wave attenuation along the zeta-shaped Gold Coast embayment and found that wave attenuation will be uneven along a non-straight coastline with respect to the incoming wave direction. This has implications for sediment transport both under extreme wave events and milder conditions (Vieira da Silva et al., 2018).

As a result a regional experiment was established within the Gold Coast embayment, with five different sections of coastline (approximately $1 \mathrm{~km}$ long) regularly surveyed in order to assess variability in response of the beach and surf zone morphology to the incoming wave climate. The data set is the first of its kind to collect regular, ongoing, high spatial resolution survey at a local-regional scale for the full profile between the foredune and depth of closure. This paper will focus upon the importance of collecting such a data set and provide a qualitative description of morphological change with respect to wave climate, using specific examples.

\section{Study Area}

The Gold Coast open ocean coastline stretches for $37 \mathrm{~km}$ and consists of eight sandy beaches separated by non-enclosing rocky outcrops. The coastline is zetashaped with beaches of the southern Gold Coast facing north and the coast curving around to be east facing in the north. The Gold Coast is subject to a moderate to 
high wave energy environment with significant seasonal and inter-annual variability (Hemer and Griffin, 2010, Morim et al., 2016). The open ocean beaches of the Gold Coast are wave-dominated and microtidal (average tidal range $=1 \mathrm{~m}$; maximum spring tidal range $=2.1 \mathrm{~m})$ (Kobashi et al., 2014). A detailed explanation of the Gold Coast open beaches wave climate is presented in Vieira da Silva et al. (2018). Due to the exposure of the coastline and dominant SE wave energy source the importance of the longshore current is increased with respect to beach morphodynamics and variability in beach state as shown by Strauss et al. (2006), Strauss and Tomlinson (2009) and Price and Ruessink (2011).

Beaches are composed of fine-grained well-sorted sand with a $\mathrm{D}_{50}$ of $0.2 \mathrm{~mm}$ (Kobashi et al., 2014). Five study sites of approximately $1000 \mathrm{~m}$ in alongshore length were chosen to represent different sections and orientations of the zetashaped coastline. The five sites exhibit slightly different exposures to the incoming wave field (Figure 1). All sites cycle through the six wave-dominated beach states defined in Wright and Short (1984) with a tendency towards the intermediate states, characterised by bar and rip morphology. For the most part the study sites display complex double bar morphology.

The three northern-most study sites (The Spit, Surfers Paradise, Miami) sit within the $16 \mathrm{~km}$ Northern Gold Coast beach embayment, which lies between the Nerang River in the north and the small, naturally bypassed Nobby Headland in the south (Figure 1). These sites are all characterised by a rhythmic outer bar and complex low tide terrace / transverse bar rip inner bar (Short, 2000). Palm Beach is a $4 \mathrm{~km}$ embayment located within the central part of the Gold Coast open beaches. It is bordered by trained river entrance headlands at both northern and southern ends. Palm Beach is also characterised by a large offshore natural reef which influences wave transformation into the embayment. The Bilinga study site is located at the southern end of the coast, with the most sheltering of the dominant SE wave climate (Vieira da Silva et al., 2018). Bilinga is characterised by a large outer terrace located at the $-5 \mathrm{~m}$ AHD contour, which is an extension of the sand wave generated from the permanent sand bypassing system located at the southern end of the Gold Coast. 


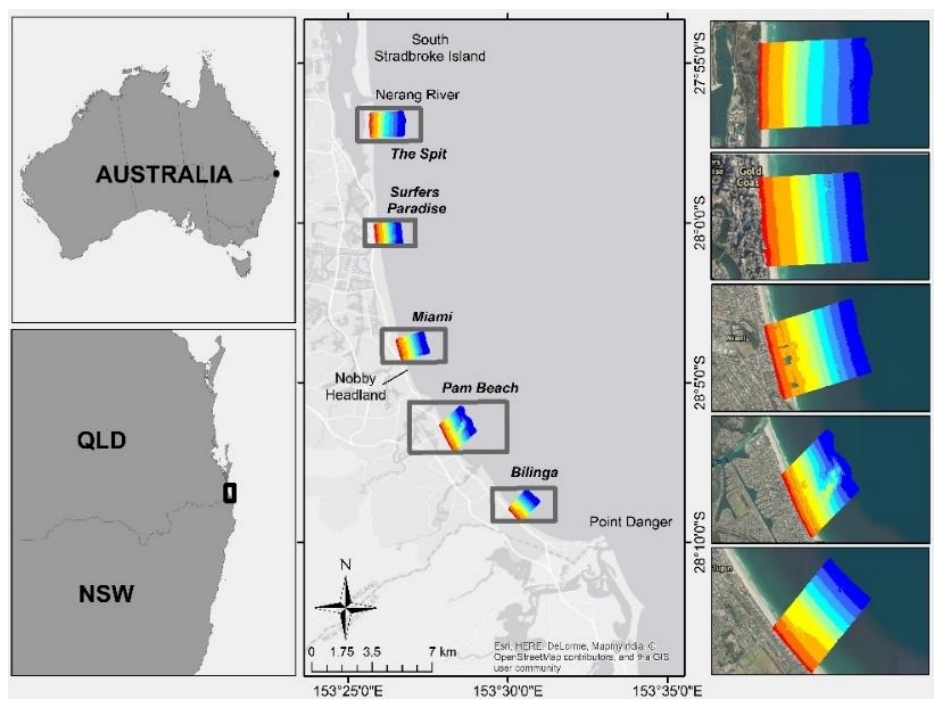

Fig. 1. Gold Coast Study Site, showing five survey locations along the zeta-shaped coastline. Colour contours represent $50 \mathrm{~m}$ spaced survey lines with warmer colours higher elevations and cooler colours lower elevations

\section{Methodology}

Standard hydrographic and topographic survey methodology were used to survey the five study sites. The beach and nearshore survey was carried out by City of Gold Coast professional survey team. Beach survey using an RTK-GPS was conducted from the top of the foredune approximately $5 \mathrm{~m}$ above local mean sea level (MSL $=0 \mathrm{~m}$ AHD, Australian Height Datum) down to approximately one metre below the MSL shoreline, defined as $0 \mathrm{~m} \mathrm{AHD.} \mathrm{Bathymetric} \mathrm{survey} \mathrm{was}$ conducted using a personal water craft (PWC), equipped with a survey-grade single beam echo sounder, RTK GNNS GPS and HYPACK ${ }^{\circledR}$ software. Nearshore survey was conducted out to the depth of closure for the region (-14 m AHD) as defined by Strauss et al. (2013). Survey lines were spaced $50 \mathrm{~m}$ apart in order to accurately survey beach and surf zone morphology on the order of tens of metres which on the Gold Coast open beaches is considered accurate enough to resolve bar and rip current morphology.

Profile lines are analysed between 4.9 m AHD and -14 m AHD, with the upper limit being defined as the position of the A-line (i.e. the crest of a continuous buried rock wall that extends the length of the Gold Coast open beaches as a last line of defence covered by an artificial dune). The lower limit is defined as the depth of closure. Profile lines are historically titled as "ETA" lines and are 
numbered from south to north. A Digital Terrain Model (DTM) was created for each survey at each of the five study sites. Data was interpolated to a $10 \times 5 \mathrm{~m}$ grid for comparison.

Bar migration both onshore and offshore was measured from the middle of the bar crest between consecutive surveys to give an indication of migration through time. An example of a storm event and subsequent accretionary period are presented in this paper. Profile lines extracted to analyse bar migration were taken from a $500 \mathrm{~m}$ alongshore section in the middle of each study site. Profiles every $100 \mathrm{~m}$ were analysed to highlight variability in bar migration within and between each study site.

Half-hourly averaged, directional wave data was recorded from the Brisbane Wave Buoy located in $70 \mathrm{~m}$ water depth, approximately $60 \mathrm{~km}$ NNE of the Gold Coast study site.

\section{Results and Discussion}

The results and discussion presented here will firstly summarise the collection of the dataset and its potential uses for investigating a variety of coastal morphodynamic questions. Secondly two examples of how the data set may be used will be presented in terms of (a) spatial variability of beach morphology due to exposure to the incoming wave climate, and (b) two examples of nearshore sand bar migration (both on and offshore) will also be presented.

\section{Collection of the Dataset}

The City of Gold Coast survey program began in June 2016, with the monitoring program currently ongoing at the five study sites. Table 1 presents the frequency of survey at each of the five study sites. Whilst the aim has been for survey to be conducted as regularly as every four to eight weeks, due to the high energy nature of the coastline, logistics and resources involved in undertaking the survey, and high stakeholder usage of the area, the monitoring program has been limited to 14 individual surveys at The Spit, Surfers Paradise and Miami and 17 individual surveys at Palm Beach and Bilinga between June 2016 and November 2018 (Table 1). This ongoing dataset is considered to be unique in the field as the most regularly updated local-regional high spatial frequency survey of the beach and nearshore (out to depth of closure). 
Table 1. Survey frequency at each of the five storm bar sites as of December 2018

\begin{tabular}{|c|c|c|c|c|c|c|c|c|c|c|c|c|}
\hline & \multicolumn{12}{|c|}{ Calendar Month of Survey } \\
\hline & 1 & 2 & 3 & 4 & 5 & 6 & 7 & 8 & 9 & 10 & 11 & 12 \\
\hline 2016 & & & & & & $\begin{array}{l}\text { TS } \\
\text { SP } \\
\text { MI } \\
\text { PB } \\
\text { BI }\end{array}$ & & $\begin{array}{l}\text { TS } \\
\text { SP } \\
\text { MI } \\
\text { PB } \\
\text { BI }\end{array}$ & & $\begin{array}{l}\text { TS } \\
\text { SP } \\
\text { MI } \\
\text { PB } \\
\text { BI }\end{array}$ & $\begin{array}{l}\text { PB } \\
\text { BI }\end{array}$ & \\
\hline 2017 & $\begin{array}{l}\text { TS } \\
\text { SP } \\
\text { MI } \\
\text { PB } \\
\text { BI }\end{array}$ & $\begin{array}{l}\text { PB } \\
\text { BI }\end{array}$ & $\begin{array}{l}\text { PB } \\
\text { BI }\end{array}$ & & $\begin{array}{l}\text { TS } \\
\text { SP } \\
\text { MI } \\
\text { PB } \\
\text { BI }\end{array}$ & $\begin{array}{l}\text { TS } \\
\text { MI } \\
\text { PB } \\
\text { BI }\end{array}$ & $\begin{array}{l}\text { TS } \\
\text { SP } \\
\text { MI } \\
\text { PB } \\
\text { BI }\end{array}$ & & & $\begin{array}{l}\text { TS } \\
\text { SP } \\
\text { MI } \\
\text { PB } \\
\text { BI }\end{array}$ & & \\
\hline 2018 & $\begin{array}{l}\text { TS } \\
\text { SP } \\
\text { MI } \\
\text { PB } \\
\text { BI }\end{array}$ & & $\begin{array}{l}\text { TS } \\
\text { SP } \\
\text { MI } \\
\text { PB } \\
\text { BI }\end{array}$ & & $\begin{array}{l}\text { MI } \\
\text { PB } \\
\text { BI }\end{array}$ & $\begin{array}{l}\text { SP } \\
\text { MI }\end{array}$ & $\begin{array}{l}\text { TS } \\
\text { SP } \\
\text { MI } \\
\text { PB } \\
\text { BI }\end{array}$ & & $\begin{array}{l}\text { PB } \\
\text { BI }\end{array}$ & & $\begin{array}{l}\text { TS } \\
\text { SP } \\
\text { MI }\end{array}$ & \\
\hline
\end{tabular}

* TS = The Spit; SP = Surfers Paradise; MI = Miami; PB = Palm Beach; BI = Bilinga. Only months where the full $50 \mathrm{~m}$ spaced survey from foredune to depth of closure are reported here. Two surveys were conducted at Palm Beach and Bilinga in October 2017.

Changes in beach volume, beach width, shoreline and depth contour position and sand bar migration can be quantified from this dataset through time and directly related to the nearshore wave climate. The regular survey also captured in detail a large scale nearshore nourishment campaign, whereby 3 million cubic metres of sediment were placed in the nearshore zone between $-2 \mathrm{~m}$ and $-10 \mathrm{~m}$ AHD between June and October 2017. An analysis of nourishment dispersion, effects on nearby morphology, volume and beach width are in progress (including numerical modelling) but are beyond the scope of this paper.

\section{Spatial Variability in Morphology with Respect to Wave Direction}

Two examples are presented below to explore the influence of wave direction on spatial variability in beach state along a non-straight, open ocean coastline. Figure 2 presents the beach and nearshore survey at each of the five study sites for May 2017. Prior to the date of survey, two weeks of $1.5-3 \mathrm{~m} \mathrm{Hs}$ waves from the ESE were recorded by the Brisbane directional wave buoy (Figure 2f). Easterly waves are more shore normal on the northern Gold Coast open beaches and previous studies have shown the easterly wave direction to encourage cellular current circulation and rhythmic bar and beach morphology (Browne et al., 2006, Strauss et al., 2006, Strauss and Tomlinson, 2009, Price and Ruessink, 2011, Price 
et al., 2011). As a result rhythmic bar and beach morphology was observed at all the five study sites (Figure 2a-e). A slight decreasing trend in beach state energy from north to south is observed with Transverse Bar and Rip Morphology (TBR) at The Spit and Surfers Paradise, Transverse Bar Rip / Low Tide Terrace (LTT) state at Miami, and lower energy inshore rhythmic Low Tide Terrace beach state at Palm Beach and Bilinga. This decrease in beach energy state from north to south supports modelled wave attenuation results presented in Vieira da Silva et al. (2018). Under easterly wave conditions their study showed minimal wave attenuation along the northern Gold Coast open beaches between The Spit and Surfers Paradise, with slightly less wave energy arriving at Miami. Under the same conditions greater wave attenuation was found at Palm Beach and Bilinga (Vieira da Silva et al., 2018), which supports the lower energy beach state observed under these wave conditions (Figure 2).

Figure 3 presents the beach and nearshore survey at each of the five study sites for July 2017. Two large SE swell events were recorded in June 2017 and followed by a moderate S-SE wave event through the start of July (Figure 3f). These conditions led to a 'resetting' of the beach and bar morphology to a more linear state along the coast (Figure 3a-e). Waves from the S-SE have been shown to drive strong longshore currents and as a result more linear bar and beach morphology (Browne et al., 2006, Strauss et al., 2006, Strauss and Tomlinson, 2009, Price and Ruessink, 2011, Price et al., 2011). The northern Gold Coast beaches of The Spit, Surfers Paradise and Miami all displayed Linear Bar and Trough (LBT) morphology in the July 2017 survey (Figure 3a-c). Palm Beach also displayed LBT morphology albeit a slightly lower energy state in the morphology with the offshore bar less well-defined and not as far detached from the shoreline as the sites to the north. Due to the nature of the well-developed offshore terrace at Bilinga and increased wave attenuation at the site under S-SE wave direction (Vieira da Silva et al., 2018) no longshore bar was present at Bilinga in the July 2017 survey (Figure 3e).

The large scale nearshore nourishment campaign can be seen at Surfers Paradise, Miami and Palm Beach in the July 2017 survey. Vieira da Silva et al. (2018) showed a strong increase in wave attenuation from north to south under a southerly wave direction, due to the shadowing effects of Point Danger. Whilst the decrease in beach state energy can be observed at Palm Beach and Bilinga (Figure 3d,e) all three of the northern open beaches present similar beach state energy (Figure 3a-c). This supports the arguments of Strauss et al. (2006) and Price and Ruessink (2011) that wave direction plays as strong a role in determining beach state as does wave energy, on an exposed open coast, nonembayed beach. 

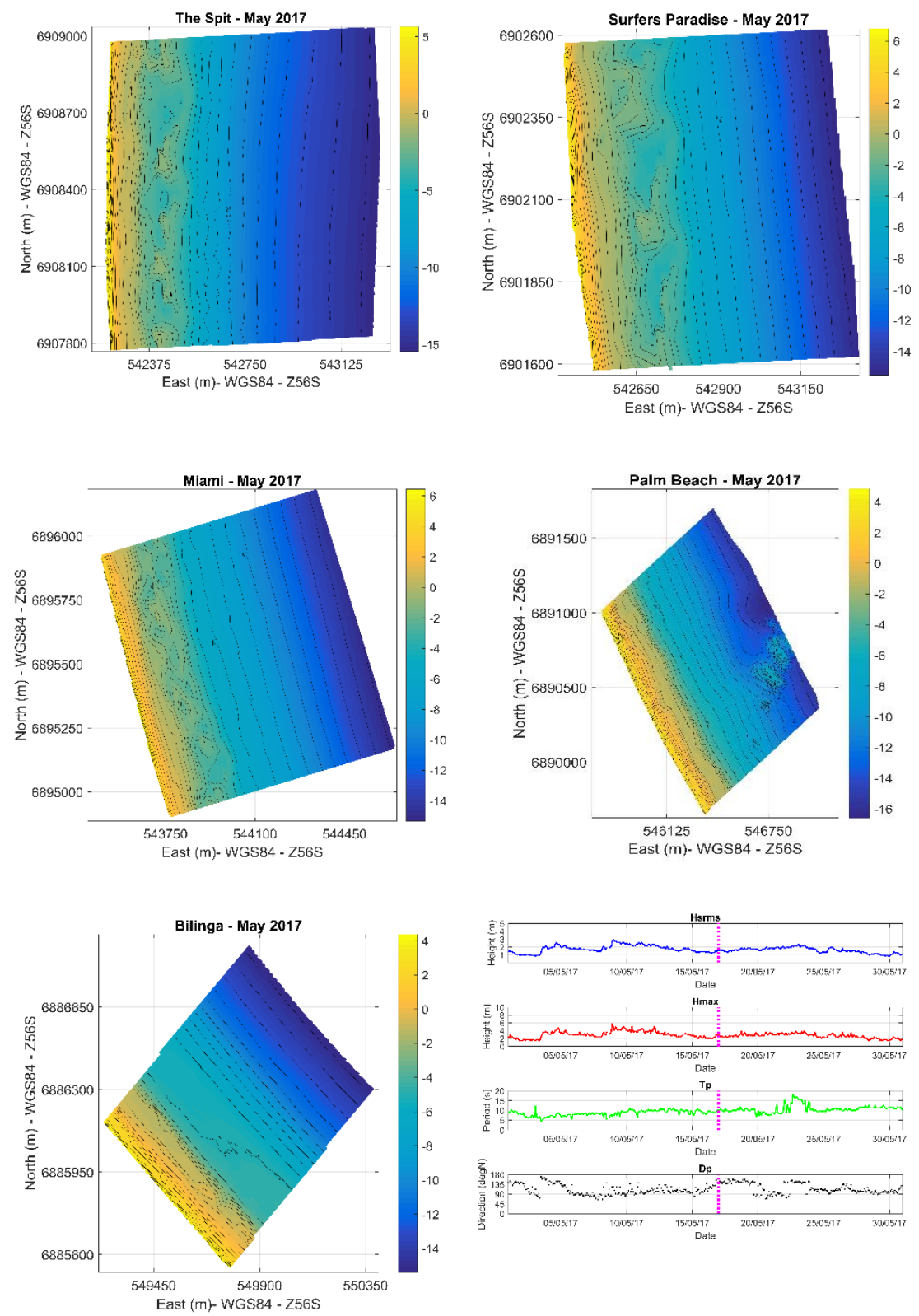

Fig. 2. Digital Terrain Model (DTM) of the beach and nearshore topography at (a) The Spit (b) Surfers Paradise (c) Miami (d) Palm Beach (e) Bilinga for May 2017 survey. The May 2017 offshore wave climate is also presented (f) with the magenta dashed line representing survey date 

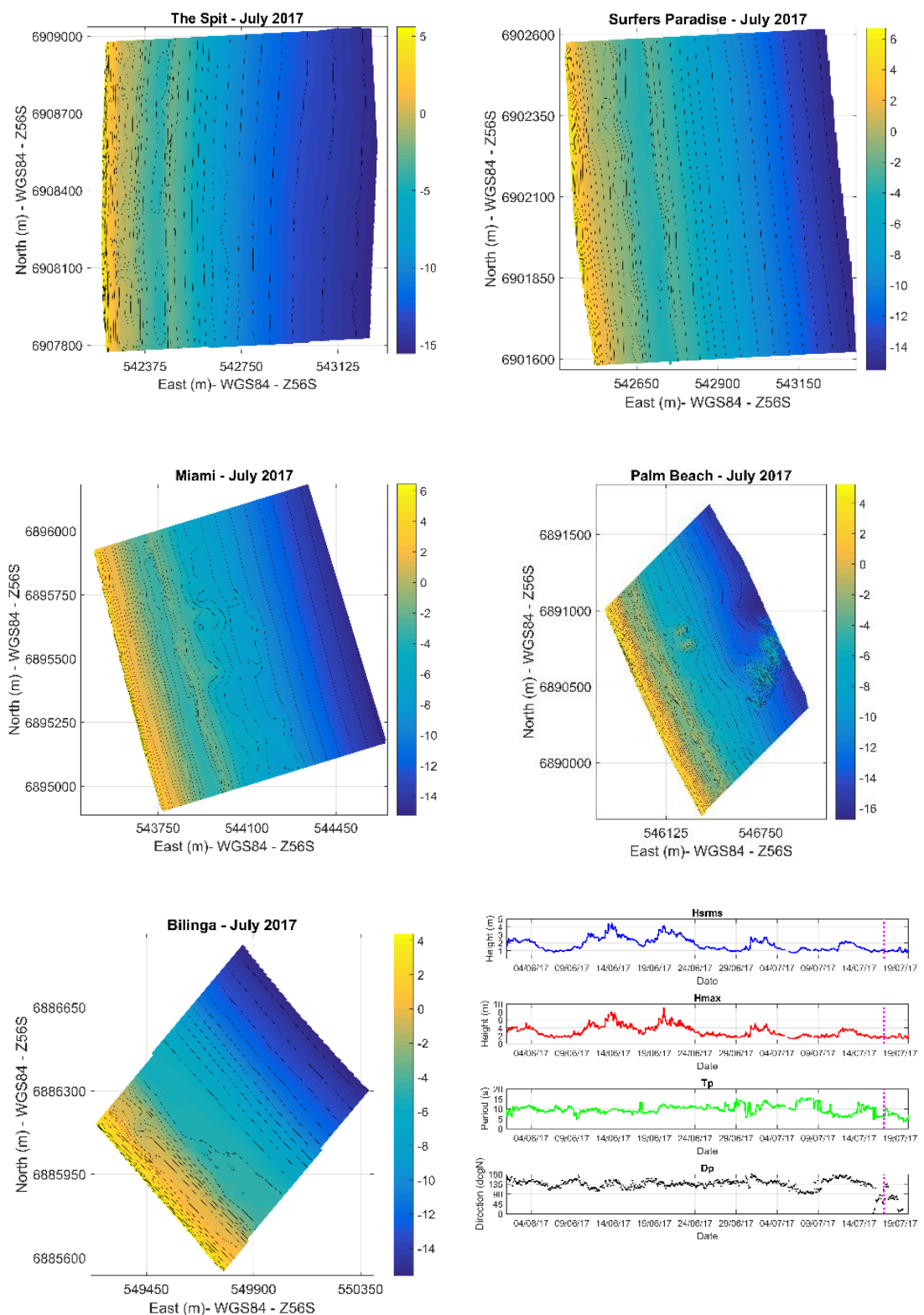

Fig. 3. Digital Terrain Model (DTM) of the beach and nearshore topography at (a) The Spit (b) Surfers Paradise (c) Miami (d) Palm Beach (e) Bilinga for July 2017 survey. The June-July 2017 offshore wave climate is also presented (f) with the magenta dashed line representing survey date. 


\section{Bar Migration}

Another dataset that is under-represented in the literature is regular tracking of bar migration, particularly onshore bar migration. The following section provides an example of offshore bar movement during a storm event and an example of onshore bar migration during an accretionary period.

\section{Offshore bar migration (erosion event)}

Survey was undertaken at Palm Beach pre and post an erosion event with significant wave heights over $3 \mathrm{~m}$ recorded from the east followed by a shortlived 2 to $3 \mathrm{~m}$ south-southeast swell event (Figure 4). An example of offshore bar migration (at profile ETA 32.5) is presented in Figure 4. The survey dates were 10 days apart and as such capture the profile both immediately before and immediately after the large wave events (Figure 4). At ETA 32.5 the bar migrated $96 \mathrm{~m}$ offshore and the crest became $0.98 \mathrm{~m}$ deeper following the storm (Figure 4). Table 2 presents the bar migration statistics in both the cross-shore and vertical direction between the two surveys. The formation of the shore-parallel linear bar crest along the $600 \mathrm{~m}$ stretch of surveyed coast displayed some variability with offshore migration ranging between 36 and $96 \mathrm{~m}$ and depth changes between 0.07 $\mathrm{m}$ and $1.25 \mathrm{~m}$ (Table 2).
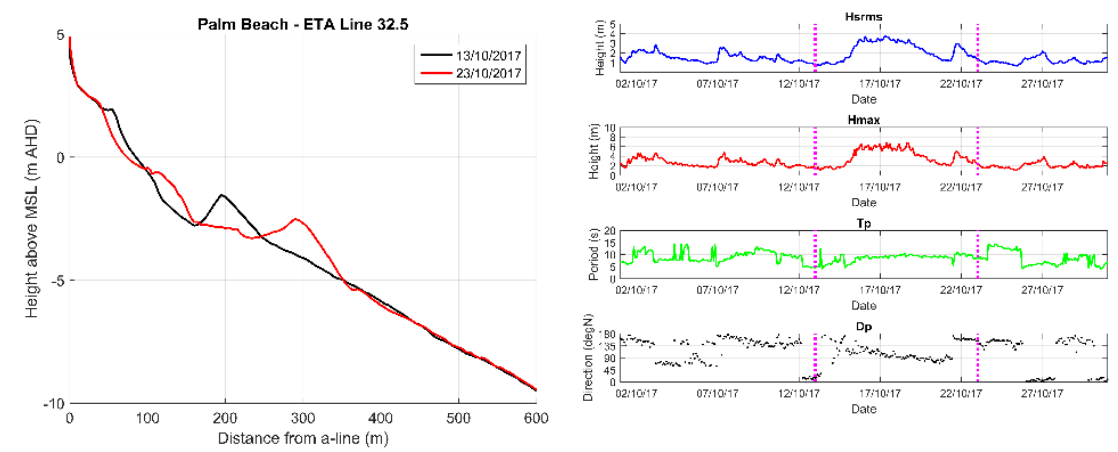

Fig. 4. Example of offshore bar migration at Palm Beach (left). Wave data for the period is presented for the Bisbane Wave Buoy (right). Magenta dashed lines represent survey dates.

Onshore bar migration (accretionary sequence)

Onshore bar migration data is less commonly collected.. A cross-sectional profile at The Spit site is extracted to provide an example of an accretionary sequence of a surf zone bar between 23/6/2016 and 5/10/2016 (Figure 5). For the majority of the June to October 2016 period the wave conditions were moderate with $\mathrm{H}_{\mathrm{s}}$ less 
than $3 \mathrm{~m}$ (Figure 5). Two large SE swell events occurred in July and August 2016 with $\mathrm{H}_{\mathrm{s}}$ exceeding $3 \mathrm{~m}$ (Figure 5) after which wave energy remained low until the October 2016 survey date (Figure 5). Despite the large wave energy events overall the surf zone bar at The Spit migrated onshore during this period and the dataset allows for an estimation of onshore migration rates. At ETA 77.75 the onshore bar migration was approximately $33 \mathrm{~m}$ between the June and August 2016 surveys and a further $37 \mathrm{~m}$ between the August and October 2016 surveys (Figure 5). Over the 104 day survey period this equates to an average shoreward migration rate of $0.67 \mathrm{~m}$ per day. During that time the bar crest reduced its depth (shallowing) by around $0.70 \mathrm{~m}$ (Figure 5). The sub-aerial beach (above $0 \mathrm{~m} \mathrm{AHD)} \mathrm{was} \mathrm{also}$ observed to accrete between the June and August surveys and remained fairly stable until the October 2016 survey (Figure 5).
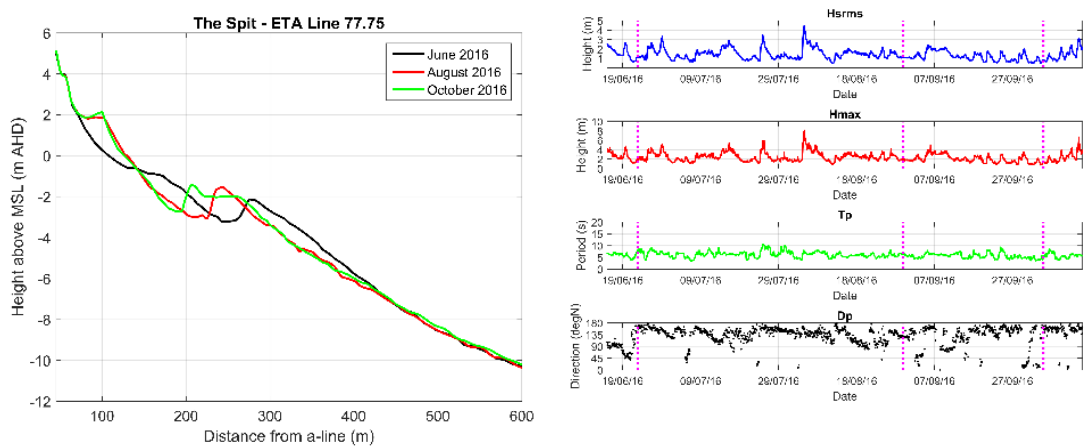

Fig. 5. Example of onshore bar migration at The Spit (left). Wave data for the accreitonary period is presented for the Bisbane Wave Buoy (right). Magenta dashed lines represent survey dates.

Whilst analysing a single profile provides important information on cross-shore bar migration, changes in the surf zone morphology are inherently three dimensional and as such a single profile is not a complete portrayal of bar movement. Tables 3 and 4 display the average cross-shore and vertical migration statistics for the accreting surf zone bar at each of the five study sites for the June - October 2016 survey period. Statistics are averaged from a $500 \mathrm{~m}$ alongshore section of the survey located in the middle of each survey site, with five crossshore transects at $100 \mathrm{~m}$ spacing analysed.

The maximum onshore bar migration over the 104 day period is similar at The Spit, Surfers Paradise, Miami and Palm Beach. The average rate of movement of the nearshore bar per day is also similar for those four survey sites. The averaged statistics for onshore bar migration at The Spit and Surfers Paradise are similar, 
with Miami and Palm Beach exhibiting more variability and lower minimum migration rates (Tables $2 \& 3$ ). There does however appear to be an increase in the vertical movement of the nearshore bar at the more exposed sections of coastline (Tables $2 \& 3$ ). Bilinga remains very stable during the period, with the surf zone bar moving slightly offshore (Table $2 \& 3$ ).

Table 2. Cross-shore movement of the sand bar crest at each study site

\begin{tabular}{|c|c|c|c|c|c|c|c|c|}
\hline \multirow[b]{2}{*}{ Survey Site } & \multicolumn{4}{|c|}{ Total Change (m) } & \multicolumn{4}{|c|}{ Change Per Day (m) } \\
\hline & $\operatorname{Max}$ & Min & Mean & Stdev & Max & Min & Mean & Stdev \\
\hline The Spit & 127 & 45 & 85.3 & 26.0 & 1.2 & 0.4 & 0.8 & 0.2 \\
\hline $\begin{array}{l}\text { Surfers } \\
\text { Paradise }\end{array}$ & 129 & 42 & 79.0 & 37.3 & 1.2 & 0.4 & 0.8 & 0.4 \\
\hline Miami & 123 & 21 & 82.2 & 39.8 & 1.2 & 0.2 & 0.8 & 0.4 \\
\hline Palm Beach & 124 & 5 & 71.3 & 44.2 & 1.2 & 0.0 & 0.7 & 0.4 \\
\hline Bilinga & -17 & 0 & -9.0 & 8.5 & -0.16 & 0.0 & -0.1 & 0.1 \\
\hline \multicolumn{9}{|c|}{$\begin{array}{l}\text { * Positive values equate to onshore migration, whilst negative values equate to offshore } \\
\text { migration. Data is taken from a } 500 \mathrm{~m} \text { alongshore section located in the middle of each survey } \\
\text { site with bar migration measured at profiles spaced every } 100 \mathrm{~m} \text {. }\end{array}$} \\
\hline & \multicolumn{4}{|c|}{ Total Change (m) } & \multicolumn{4}{|c|}{ Change Per Day (m) } \\
\hline Survey Site & Max & Min & Mean & Stdev & Max & Min & Mean & Stdev \\
\hline The Spit & 4.79 & 0.70 & 1.76 & 1.38 & 0.05 & 0.01 & 0.02 & 0.01 \\
\hline $\begin{array}{l}\text { Surfers } \\
\text { Paradise }\end{array}$ & 2.07 & 1.13 & 1.48 & 0.41 & 0.02 & 0.01 & 0.01 & $<0.01$ \\
\hline Miami & 2.48 & 0.43 & 1.57 & 0.83 & 0.02 & 0.01 & 0.02 & 0.01 \\
\hline Palm Beach & 1.90 & 0.0 & 0.95 & 0.78 & 0.02 & 0.01 & 0.01 & 0.01 \\
\hline Bilinga & -0.47 & -0.20 & -0.37 & 0.15 & $\begin{array}{c}<0.0 \\
1\end{array}$ & $\begin{array}{c}<0.0 \\
1\end{array}$ & $<0.01$ & $<0.01$ \\
\hline
\end{tabular}

* Positive values equate to decreasing depth (shallowing), whilst negative values equate to increasing depth (deepening). Data is taken from a $500 \mathrm{~m}$ alongshore section located in the middle of each survey site with bar migration measured at profiles spaced every $100 \mathrm{~m}$. 


\section{Conclusion}

This paper summarises an ongoing, high spatial resolution survey effort to monitor several sections of beach and nearshore along a non-straight open ocean coastline. The survey program is regularly undertaken by the City of Gold Coast and has been shown to be useful for providing information on spatial and temporal variability of beach morphodynamics at a local to regional scale. The paper highlights the spatial variability of beach state under two different wave conditions, shore-normal and shore-oblique and for variable wave heights. The results highlight the effect of wave attenuation along the coastline on beach state energy as well as supporting the theory that wave direction on non-embayed coastlines plays an important role in determining beach state. Whilst further data collection will improve our understanding of onshore sand bar migration an example of the power of the dataset to provide such information is provided in this paper. Furthermore by extracting cross-sectional profiles from the survey and tracking the bar crest through time onshore bar migrations rates can be estimated with better confidence and accuracy. In the future the dataset will also be used to quantify the spatial and temporal variability in beach state at both a local and regional scale with respect to wave direction and energy flux. The knowledge gained from this dataset will be able to directly inform coastal management and mitigation at a local to regional scale with different sections of the coast responding differently to the varying wave climate through time.

\section{Acknowledgements}

This research project was sponsored by the City of Gold Coast (the City) through a funding and collaboration agreement between the City and Griffith University. The City has provided data, including bathymetric survey, and project overview to assist in the understanding of this research topic and its benefit to the City. This research was also supported by an Advance Queensland Research Fellowship, number AQRF02815-16RD1.

\section{References}

Adams, P., Inman, D.L., and Lovering, J.L. 2011. "Effects of climate change and wave direction on longshore sediment transport patterns in Southern California," Climatic Change, 109, 211-228

Bonnetti, J., Klein, A.H.F., Muller, M., de Luca, C.B., Vieira da Silva, G.V., Toldo Jr, E.E., and Gonzales, M. 2012. "Spatial and numerical methodologies on coastal erosion and flooding risk assessment," Coastal Research Libraty Series, Springer, Dordrecht, ISBN: 978-94-007-5233-7, 
$423-442$

Browne, M., Strauss, D., Tomlinson, R., and Blumenstein, M. 2006. “Objective beach state classification from optical sensing of cross-shore dissipation profiles," IEEE Transactions on Geoscience and Remote Sensing, 44, 34183426.

Bryan, K.R., Foster, R., and Macdonald, I. 2013. "Beach rotation at two adjacent headland-enclosed beaches," Journal of Coastal Research, SI65(2), 20952100 .

Elgar, S., Gallagher, E.L., and Guza, R.T. 2001. "Nearshore sandbar migration," Journal of Geophysical Research, 106, 11623-11627.

Gallagher, E., Elgar, S., and Guza, R.T. 1998. "Observations of sand bar evolution on a natural beach," Journal of Geophysical Research, 103, 3203 -3215 .

Gallop, S.L., Harley, M.D., Brander, R.W., Simmons, J.A., Splinter, K.D., and Turner, I.L. 2017. "Assessing cross-shore and alongshore variation in beach morphology due to wave climate: storms to decades," Oceanography, $30(3), 120-125$.

Harley, M.D., Turner, I.L., Kinsela, M.A., Middleton, J.H., Mumford, P.J., Splinter, K.D., Phillips, M.S., Simmons, J.A., Hanslow, D.J., and Short, A.D. 2017. "Extreme coastal erosion enhanced by anomalous extratropical storm wave direction," Scientific Reports, 7, 6033.

Harley, M.D., Turner, I.L., and Short, A.D. 2015. "New insights into embayed beach rotation: The importance of wave exposure and cross-shore processes," Journal of Geophysical Research: Earth Surface, 120, 14701484.

Hemer, M.A., and Griffin, D.A. (2010). "The wave energy resource along Australia's southern margin," Journal of Renewable and Sustainable Energy, 2, 0413108.

Hoefel, F., and Elgar, S. 2003. "Wave-induced sediment transport and sandbar migration," Science, 299, 1885-1887.

Klein, A.H.F, Filho, L.B., and Schumacher, D.H. 2002. "Short-Term Beach Rotation Processes in Distinct Headland Bay Beach Systems," Journal of 
Coastal Research, 18, 442-458.

Kobashi, D., Strauss, D., and Tomlinson, R. 2014. "Changing Coastlines and Processes," In: Burton, P. (ed.) Responding to Climate Change: Lessons from an Australian Hotspot, CSIRO Publishing, Collingwood, 203 p.

Morim, J., Cartwright, N., Etemad-Shahidi, A., Strauss, D., and Hemer, M.A. 2016. "Wave energy resource assessment along the Southeast coast of Australia on the basis of a 31-year hindcast," Applied Energy, 184, 276297.

Mortlock, T.R., and Goodwin, I.D. 2005. "Directional wave climate and power variability along the Southeast Australian shelf," Continental Shelf Research, 98, 36-53.

Mortlock, T.R., Goodwin, I.D., Mcaneny, 2017. “The June 2016 Australian East Coast Low: Importance of Wave Direction for Coastal Erosion Assessment," Water 2017, 9, 121.

Price, T.D., and Ruessink, B.G. 2011. "State dynamics of a double sandbar system," Continental Shelf Research, 31, 659-674.

Price, T.D., Rutten, J., and Ruessink, B.G. 2011. "Coupled behaviour within a double bar sandbar system," Proceedings of the 11th International Coastal Symposium 2011, Poland, 5 p.

Roelvink, J.A., and Stive, M.J.F. 1989. "Bar-generating cross-shore flow mechanisms on a beach," Journal of Geophysical Research, 94, 4785-4800.

Short, A.D. 2000. "Beaches of the Queensland coast: Cooktown to Coolangatta: a guide to their nature, characteristics, surf and safety, , Sydney, Sydney University Press, 360 p.

Short, A.D., and Trembanis, A.C. 2004. "Decadal scale patterns in beach oscillation and rotation Narrabeen Beach, Australia - Time series, PCA and wavelet analysis," Journal of Coastal Research, 20, 523-532.

Short, A.D., Trembanis, A.C., and Turner, I.L. 2000. "Beach oscillation, rotation and the Southern oscillation, Narrabeen Beach, Australia," Abstracts of the 27th International Conference on Coastal Engineering (ICCE) '00, Sydney, Australia 14 p. 
Strauss, D., Burston, J., Gririndel, T., and Tomlinson, R. 2013. "Multi-decadal analysis of profile response to permanent bypassing," Coastal Dynamics $2013,1547-1558$.

Strauss, D., and Tomlinson, R. 2009. "Modelling transitions between barred beach states on a straight coast," Proceedings of Coastal Dynamics 2009, Tokyo, Japan, 12 p.

Strauss, D., Tomlinson, R., and Hughes, L. 2006. "Numerical modelling and video analysis of intermediate beach state transitions," The $7^{\text {th }}$ International Conference on Hydroscience and Engineering (ICHE 2006), Philadelphia, USA, $17 \mathrm{p}$.

Vieira da Silva, G., Gomes da Silva, G., Klein, A.H.F., Toldo Jr., E.E., and Araujo, R.S. 2017. "Wave run-up on embayed beaches. Study case: Itapocorói Bay, southern Brazil,” Brazilian Journal of Oceanography, 62(2), 187-200.

Vieira da Silva, G., Murray, T., and Strauss, D. 2018. "Longshore wave variability along non-straight coastlines," Estuarine and Coastal Shelf Science, 212, 318-328.

Wright, L.D., and Short, A.D. 1984. "Morphodynamic variability of surf zones and beaches: a synthesis," Marine Geology, 56, 93-118. 